\title{
Uluslararası İlişkilerde Kaynayan Sular: Güney Çin Denizi
}

\author{
Diren DOĞAN
}




\section{(C) Copyright 2021}

Bu kitabın, basım, yayın ve satış hakları Akademisyen Kitabevi A.Ş.'ye aittir. Anılan kuruluşun izni alınmadan kitabın tümü ya da bölümleri mekanik, elektronik, fotokopi, manyetik kağıt ve/veya başka yöntemlerle çoğaltılamaz, basılamaz, dağıtılamaz. Tablo, şekil ve grafikler izin alınmadan, ticari amaçh kullanılamaz. Bu kitap T.C. Kültür Bakanlı̆̆ bandrolü ile satılmaktadır.

Bu kitapta yer alan fikirler ve düşünceler yazara ait olup, hiçbir kurum veya kuruluşun görüşünü yansıtmamaktadır. Bu kitap paylaşılan "Uluslararası İlişkilerde Kaynayan Sular: Güney Çin Denizi” adlı yüksek lisans tezinden üretilmiştir.

\section{ISBN}

978-625-7496-76-6

\section{Kitap Adı}

Uluslararası İlişkilerde Kaynayan Sular: Güney Çin Denizi

\section{Editör}

Prof. Dr. Muharrem Gürkaynak

ORCID iD: 0000-0002-5371-0474

Yazar

Diren DOĞAN

ORCID iD: 0000-0002-6021-2828

\section{Yayın Koordinatörü \\ Yasin DİLMEN}

\section{Sayfa ve Kapak Tasarımı \\ Akademisyen Dizgi Ünitesi}

\section{Yayıncı Sertifika No}

47518

\section{Baskı ve Cilt}

Vadi Matbaacillk

Bisac Code

POL011000

\section{DOI}

10.37609/akya.708

\section{GENEL DAĞITIM}

\section{Akademisyen Kitabevi A.Ş.}

Halk Sokak 5 / A

Yenişehir / Ankara

Tel: o312 4311633

siparis@akademisyen.com 


\section{ÖNSÖZ}

Devletlerin uluslararası sistemdeki varlıkları; sahip oldukları ekonomik, askeri ve sosyolojik olguların yanı sıra, bu olguların oluşumu sırasında gösterdikleri reflekslerle paralel biçimde ilerlemektedir. Uluslararası sistemin yegâne aktörü kabul edilen devletlerin dış sınırlarını çevreleyen miğfer konumundaki bu refleksler, diğer aktörlerin faaliyetlerinden önce göz önünde bulunduracağ1 temel göstergelerin başında gelmektedir. Bu doğrultuda bu çalışmada ele alınan ihtilaflar, Asya-Pasifik Bölgesi içerisinde yer alan, "Güney Çin Denizi” olarak adlandırılan bölgenin kıyısında bulanan ülkeleri kapsamakta ve ihtilafa taraf olan ülkelerin sayısı ve de çeşitliliği açısından küresel bazdaki diğer örneklerinden tamamen ayrılmaktadır. Bu noktada, "Dünya üzerindeki bölgesel ihtilafların hiçbiri en az beş hak talebini içeren Güney Çin Denizi ihtilafi kadar fazla aktörlü ve karmaşık değildir.” yargısında bulunmak, çalışmanın değeri açısından yerinde bir tespit olacaktır. Aynı zamanda, ihtilafa dâhil olan kıyı devletlerin ihtilafa yönelik gösterdiği farklı refleksler; hayati çıkar noktasından, pragmatist pasiflik noktasına kadar uzayabilirken; Güney Çin Denizi'nin sahip olduğu jeo-politik ve jeo-stratejik özelliklerin getirdiği artılar ise, özellikle 21. yüzyllın gereklilikleriyle birleştiğinde, bu bölgenin üçüncü dünya savaşının merkezi konumuna gelebileceğini gözler önüne sermektedir. Diğer taraftan bu durum, sahip olduğu gücü ve kapasitesiyle Çin Halk Cumhuriyeti'nin Güney Çin Denizi'ne yönelik politikalarını merak ve şüpheyle sorgulatmaktadır. Özellikle de 2016 yılında Çin Halk Cumhuriyeti aleyhine sonuçlanan Tahkim Mahkemesi Kararı'nın ardından, kapasitesini gün geçtikçe arttıran bu yükselen gücün atacağı adımlar ilgiyle izlenmektedir.

Bu doğrultuda elinizde bulunan çalı̧̧ma, kapsamlı bir literatür taraması neticesinde tarafsızlık ve bilimsel hassasiyetler çerçevesinde oluşturulmuştur. Tüm bu amaçlarla uluslararası literatür taranmış, farklı perspektiflerden üretilen çalışmaların çapraz okuması gerçekleştirilmiş ve özellikle ülkeler bazında ele alınan ihtilafların tarihsel çerçevesinin sağlam biçimde doldurulması amaçlanmıştır. Bir yüksek lisans tezi olarak üretilen bu çalı̧smanın yazıldığı dönemde ülkemizde konu hakkında ciddi kaynak eksikliği olduğu farkedilmiştir. Diğer taraftan Yunanistan ile Türkiye arasında yaşanan adalar sorununun makro versiyonu olan Güney Çin Denizi ihtilafının derinlemesine incelenerek uluslararası hukuk kapsamında değerlendirilmesinin, ileride Ege Denizi'ndeki egemenliği belirsiz ada, adacık ve kayalıklar sorununun çözümüne de projeksiyon sağlayabileceği düşünülmektedir. 
Annem'e ithafen 


\section{KISALTMALAR}

\begin{tabular}{|c|c|}
\hline ASEAN: & $\begin{array}{l}\text { Güneydoğu Asya Uluslar } \\
\text { Birliği }\end{array}$ \\
\hline BM: & Birleşmiş Milletler \\
\hline BMDHS: & $\begin{array}{l}\text { Birleşmiş Milletler Deniz } \\
\text { Hukuku Sözleşmesi }\end{array}$ \\
\hline BMKSK: & $\begin{array}{l}\text { Birleşmiş Milletler Kıta } \\
\text { Sahanlıkları Komisyonu }\end{array}$ \\
\hline CNOOC: & $\begin{array}{l}\text { Çin Ulusal Denizaşırı } \\
\text { (offshore) Petrol Şirketi }\end{array}$ \\
\hline ÇHC: & Çin Halk Cumhuriyeti \\
\hline DOC: & Davranış Bildirgesi \\
\hline GÇD: & Güney Çin Denizi \\
\hline KIG: & Kalayaan Adalar Grubu \\
\hline MEB: & Münhasır Ekonomik Bölge \\
\hline PLAN: & $\begin{array}{l}\text { Halk Kurtuluş Ordusu Deniz } \\
\text { Kuvvetleri }\end{array}$ \\
\hline LPG: & $\begin{array}{l}\text { Sivilaştırılmış Petrol Gazı } \\
\text { (Liquified Petroleum Gas) }\end{array}$ \\
\hline EIA: & $\begin{array}{l}\text { ABD Enerji ve Enformasyon } \\
\text { İdaresi }\end{array}$ \\
\hline USGS: & $\begin{array}{l}\text { Birleşmiş Milletler } \\
\text { Meteoroloji Araştırmaları } \\
\text { Birimi }\end{array}$ \\
\hline PMI: & Filipin Denizcilik Enstitüsü \\
\hline KIG: & Kalayaan Adaları Grubu \\
\hline GSYH: & Gayri Safi Yurtiçi Hasıla \\
\hline
\end{tabular}




\section{İÇİNDEKIILER}

GíRiş ix

\section{Bölüm 1: Güney Çin Denizi}

1. Güney Çin Denizi'nin Coğrafi Konumu . .1

2. Güney Çin Denizi'nin Yakın Tarihi ..................................................3

2.1. Güney Çin Denizi’nin Egemenlik Öncesi Tarihi..................................... 4

2.2. Güney Çin Denizi'nin Egemenlik Tarihi ................................................. 5

2.3. İkinci Dünya Savaşı Sonrasında Güney Çin Denizi .............................. 8

2.4. Birleşmiş Milletler Deniz Hukuku Sözleşmesinin İmzalanması ve

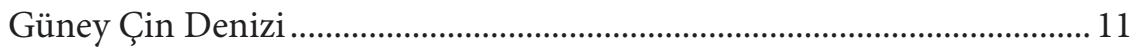

3. Güney Çin Denizi'nin Önemi .............................................................14

3.1. Yüksek Ticaret Potansiyeline Sahip Ulaşım Rotalarının

Üzerinde Bulunması...................................................................................... 14

3.2. Zengin Balıçılık ve Tabii Kaynakları.................................................... 18

3.2. Potansiyel Petrol ve Doğal Gaz Rezervleri ..........................................21

Bölüm 2:Bölgede Yer Alan Çin Halk Cumhuriyeti

Dışındaki Ülkelerin İddiaları

1. Vietnam Sosyalist Cumhuriyeti'nin İddiaları .33

1.1. Vietnam Sosyalist Cumhuriyeti’nin Egemenlik

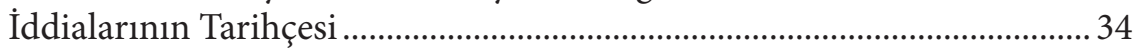

1.2. Doi Moi Politikası ve Sonrasındaki Gelişmeler ..................................... 39

1.3. Vietnam’ı BMKSK’ya Başvurmaya Yönlendiren Gelişmeler ................ 42

2. Filipinler Cumhuriyeti'nin İddiaları .............................................48

2.1. Filipinler Cumhuriyeti'nin Tarihsel İddiaları ......................................4 48

2.1. Filipinler Cumhuriyeti'nin Hukuki İddiaları......................................54

3. Malezya Devleti'nin İddiaları.............................................................58

3.1. Malezyảnın Güney Çin Denizi Stratejisi.............................................. 65

4. Brunei' in İddiaları...................................................................71

4.1. Brunei’in Güney Çin Denizi Stratejisi .................................................. 72 
Bölüm 3: Çin Halk Cumhuriyeti’nin İddiaları ve “Four Sha” Doktrini 1. Çin Halk Cumhuriyeti'nin İddiaları ....................................................75

1.1. Çin Halk Cumhuriyeti’nin GÇD’deki İddialarına Bakış.......................76

1.2. Çin Halk Cumhuriyeti’nin İddialarına Getirilen

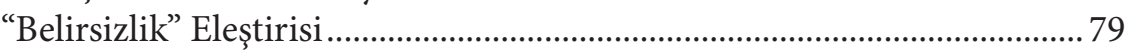

1.3. Çin Halk Cumhuriyeti'nin Tarihsel İddiaları..................................... 79

1.3.1. Çin Halk Cumhuriyeti’nin Hanlıklar Dönemindeki İddiaları... 80

1.3.1. Çin Halk Cumhuriyeti’nin İkinci Dünya Savaşı Çerçevesindeki İddiaları

1.3.2. Çin Halk Cumhuriyeti’nin Siyasi Tarih Dışındaki Stratejileri ... 83

1.3.3. Çin Halk Cumhuriyeti’nin 21. Yüzyıl İddiaları, U Şekilli Harita ve Eleştiriler .85

2. Four Sha Doktrini..............................................................................888

2.1. Four Sha Doktrini'nin Ortaya Çıkışı...................................................... 89

2.2. Four Sha Doktrini'nin Kapsam1 .................................................. 90

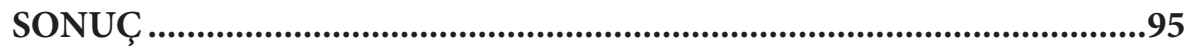

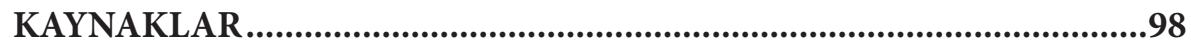




\section{KAYNAKLAR}

\section{Kitaplar}

Bateman, Sam, "Building good order at sea in Southeast Asia: the promise of international regimes”, (içinde) Ed. Kwa C., Guan-John K., Skogan, Maritime Security in Southeast Asia, Routledge Security in Asia Series, 2007.

Bateman, Sam, "Chapter 2: Good Order At Sea İn The South China Sea", (içinde) Shicun, Wu, Keyuan, Zou, Maritime Security In The South China Sea, Ashgate Pub., 2009.

Bautista, Lowell - Schofield, Clive, "Chapter 16: Philippine-China Border Relations: Cautious Engagement Amid Tensions”, (içinde) Beijing's Power And China’s Borders Twenty Neighbors In Asia, ed. Bruce Elleman vd.

Braudel, Fernand, Uygarlıkların Grameri, Çev. M.Ali Kılıçbay, İmge Yay., 1996.

Cáceres, Sigfrido B., China's Strategic Interests in the South China Sea: Power and resources, Routledge, New York, 2014.

Chung, Christopher, "Southeast Asia and the South China Sea dispute", (içinde) Ed.Sam Bateman-Ralf Emmers, Security And International Politics In The South China Sea Towards A Cooperative Management Regime, Routledge, 2009.

Cima, Ronald J., Vietnam a Country Study, Area Book Series, United States Government as represented by the Secretary of the Army, 1989. http://memory.loc.gov/master/frd/frdcstdy/vi/ vietnamcountryst00cima_0/vietnamcountryst00cima_0.pdf

David Jay, Green, The Third Option For The South China Sea: The Political Economy of Regional Conflict and Cooperation, Palgrave Macmillan (eBook), 2016.

Denk, Erdem, Egemenliği Tartışmalı Adalar: Karşılaştırmalı Bir Çalı̧̧ma (Kardak Kayalıkları Ve Spratly Ve Senkaku / Diaouyu Adaları Örnekleri, Mülkiyeliler Birliği Vakfı Yayınları, Kasım 1999, Ankara.

Downs, Erica S., China's Quest For Energy Securtty, RAND, 2000. http://www.understandchinaenergy.org/wp-content/uploads/2013/10/chinas-quest-for-energy-security-erica-downs.pdf

Forsyth, Ian, "Capter 7: Core of the Core: China's Intersts and Priorites in the South China Sea", (içinde) China and International Security: History, Strategy, and 21st-Centruy Policy, Ed. Donovan C.Chau-Thomas M. Kane, Praeger, 2014.

Gendreau, Monique C,. Sovereignty over the Paracel and Spratley Islands, Çev. Monique, C.Gendreau vd., Springer, Netherlands, 2000.

Hayton, Bill, The South China Sea The Struggle For Power In Asia, Yale University Press New Haven And London, 2014.

Huang, Jing - Billo, Andrew Territorial Disputes in the South China Sea Navigating Rough Waters, Palgrave Macmillan Press, 2015.

Kaplan, Robert D, Asia's Cauldron: The South China Sea and the end of The Stable Pasific, eBook Chapter I: The Humanist Dilemma, Random House, New York, 2005.

Khalilzad, M. Zalmay, vd., The United States and a Rising China: Strategic and Military Implications, Air Force Rand, 1999.

Lawrence,W. - Prabhakar, S. "Capter 4: The Regional Dimension of Territorial And Maritime Disputes in Southeast Asia Actors, Disagreements And Dynamics” (içinde) Kwa C., Guan-John K., Skogan, Maritime Security in Southeast Asia, Routledge Security in Asia Series, 2007.

Li, Rex, "Chapter 6: China’s Sea Power Aspirations and Strategic Behaviour in the South China Sea from the Theoretical Perspective of Identity Construction", (içinde) ed.Enrico Fels Truong-Minh Vu "Power Politics in Asia's Contested Waters Territorial Disputes in the South China Sea", Springer Pub., 2016.

Lo, Chi-Kin, China's Policy Towards Territorial Disputes-The Case of the South China Sea Islands, 
International Politics in Asia Series, Routledge, 1989.www.jstor.org/stable/4314196

Noor, Elina, "Chapter 2: Understanding Malaysia's Approach to the South China Sea Dispute", (içinde), Murray, Hiebert vd., South China Sea Disputes: Papers From the Fifth Annual CSIS South China Sea Confrence, RowmanELittlefield, September 2015.

Samuels, Marwiyn, Contest for the South China Sea, Routledge, 2005.

Schofield, Clive, "Dangerous Ground: A Geopolitical Overview Of The South China Sea”, (İçinde) Ed.Sam Bateman-Ralf Emmers, Security And International Politics In The South China Sea Towards A Cooperative Management Regime, Routledge, 2009, S.18..

Severino, Rodolfo C. Where in the World is the Philippines- Debating its National Territory, Institute of Southeast Asian Studies, ISEAS Publishing, Singapore,2011.

Shicun, Wu, Solving Disputes for Regional Cooperation and Development in the South China Sea- $A$ Chinese perspective, Chandos Publishing, 2015.

Thanh, Hai Do Vietnam's Evolving Claims İn The South China Sea, (içinde) The South China Sea and Australia's Regional Security Environmet edt. Leszek Buszynksi and Christopher Roberts. http://nsc.anu.edu.au/

Till, Geoffrey, "The South China Sea Dispute An İnternational History”, (içinde), ed. Sam Bateman-Ralf Emmers, Security and International Politics in the South China Sea, Routledge security in Asia Pacific series, 2009.

Vergin, Nur, Siyasetin Sosyolojisi, Doğan Egmont Yay., Eylül, 2008.

Weatherbee, Donald E., "International Relations in Southeast Asia: The Struggle for Autonomy, Chapter 6: The South China Sea Conflict Zone", Rowman \& Littlefield Publishers, Asia in World Politics, 2014.

Xiangjun, Zhang, "Regional Cooperation for Marine Pollution Contingency Response in the South China Sea", (içinde) Shicun, Wu-Keyuan, Zou, Maritime Security İn The South China Sea, Ashgate Pub., 2009.

Yergin, Daniel, Petrol: Para ve Güç Çatışmasının Epik Öyküsü, Çev. Kamuran Tuncay, Türkiye İş Bankası Kültür Yay., 1991.

\section{Tezler}

Arslan, Fecri, "Wallerstein'in Modern Dünya Sistemi Modeli Açısından Modernleşme Kuramı", Yüksek Lisans Tezi, Afyon Kocatepe Üniv., 2011.

Chin Yoon, Chin, "Potential For Conflict İn The Spratly İslands", Naval Postgraduate School, Thesis, Monterey-California.

Khaerani, Adında, “Güney Çin Denizi Sorunlarında Asean’ın Rolü”, Yüksek Lisans Tezi, İstanbul Üniversitesi, İstanbul, 2016. https://tez.yok.gov.tr/UlusalTezMerkezi/TezGoster?key=DPTyuy3wRPq_qvCPSqUB62-dyQBU4AtezEQbqOVfsyMzrExb-e4LPegsmmG85N5n

Malczewska, Klaudia, "Chinese Claim to the South China Sea under International Law”, Universty Of Warsaw,s.74.http://dspace.uni.lodz.pl/xmlui/bitstream/handle/11089/12510/6-067_080-Malczewska.pdf?sequence=1\&isAllowed=y

Qurachon, Mazuin, "Filipinler-Çin Güney Çin Denizi Alanları Anlaşmazlığı Karşısında Amerikan Mihver Dengeleme Stratejisi”, Yüksek Lisans Tezi, Ege Üniversitesi, 2017.

Subaşıŏlu, Doğan, “Andre Gunder Frank’da Dünya Sistemi”, Şeyh Edebali Üniv., Yüksek Lisans Tezi, 2013. 


\section{Süreli Yayınlar ve Makaleler}

Akçadağ, Emine, "Yumuşak Güç Japonyảnın Sert Güç Arayışları”, Bilge Strateji, C.2, S.3, Güz 2010.

Alexander, Metelitsa-Megan, Mercer, "World Oil Transit Chokepoints Critical To Global Energy Security",1 Aralık 2014, U.S. Energy Information Administration, https://www.eia.gov/ todayinenergy/detail.php?id=18991

Arnold, Caitlin, "Governing The South Chına Sea: From Freedom Of The Seas To Ocean Enclosure Movements", Harvard Asia Quarterly: The South China Sea, 2011.

Ataöv, Türkkaya, "1898 İspanyol-Amerikan Savaşı ve Sonuçları". http://dergipark.ulakbim.gov. tr/ausbf/article/view/5000054602/5000051913

$\mathrm{Au}$, Alderic, "Arms Race: China and the Geopolitics of the South China Sea", A Geopolitics Series Primer, 2018. https://www.amazon.com/Arms-Race-China-Geopolitics-South-ebook/ dp/B07BTY9PXQ

Bader, Jeffrey - Lieberthal, Kenneth - McDevitt, Michael, "Keeping the South China Sea in Perspective", The Foreign Policy Brief, August 2014. https://www.brookings.edu/wp-content/uploads/2016/06/south-china-sea-perspective-bader-lieberthal-mcdevitt.pdf

Başeren, Sertaç, "Münhasır Ekonomik Bölge Kıta Sahanlı̆̆ının Kavramsal Yapısını Etkileyen Bir Kurum Değildir", Türkiye Barolar Birliği Dergisi, S.1, 1995.

Bautista, Lowell, "The Philippine Treaty Limits and Territorial Water Claim in International Law”, Social Science Diliman (January 2008-December 2009), C.1, S.5.

Beşikçi, Mehmet, "1894-1895 Çin-Japon Savaşı: Japon Emperyalizminin Yükselişi ve Osmanlı İmparatorluğu”, Toplumsal Tarih Dergisi, S.161, Mayıs 2007.

Binzat, Gökhan, "Güney Çin Denizi’nde ABD ve Çin’i Savaşın Eşiğine Getiren Suni Adalar Krizi”, http://www.21yyte.org/tr/arastirma/cin-halk-cumhuriyeti/2015/06/12/8208/guney-cin-denizinde-abd-ve-cini-savasin-esigine-getiren-suni-adalar-krizi

Blusse, Leonard "No Boats to China/The Dutch East India Company and the Changing Pattern of the China Sea Trade, 1635-1690", Modern Asian Studies, C.30, S.1, February 1996.

Boquet, Yves, The Philippine Archipelago, Capter 20 "South China Sea or West Philippine Sea?", Springer Geography, France, 2017.

Buszynski, Leszek, "The South China Sea: Oil, Maritime Claims, and U.S.-China Strategic Rivalry", The Washington Quarterly, Spring 2012.

Chen, Hung-yu, "Territorial Disputes in the South China Sea under the San Francisco Peace Treaty", Issues \& Studies, S.3, September 2014.

Chong, Charles,- Wu, Han, "Common İnterests and Two-Level Game Theory in the South China Sea”, American Journal of Chinese Studies, C. 23, Special İssue 1 (JULY 2016).

Constance, Johnson, "China; Vietnam: South China Sea Agreement", Library of Congress, 17 October 2011, http://www.loc.gov/law/foreign-news/article/china-vietnam-south-china-sea-agreement/

Cruz De Castro, Renato, "The Philippines in the South China Sea dispute", The South China Sea and Australia’s Regional Security Environment, National Security College. http://nghiencuuquocte.net/wp-content/uploads/2014/07/The-Philippines-in-the-South-China-Sea-dispute.pdf

Çınar, Burak, “İkinci Dünya Savaşıında Almanyảnın İki Cepheli Savaş Sorunu”, Güvenlik Stratejileri Dergisi, S.20, 2010.

Davis, Malcolm, "China's Strategic Strait in the South China Sea (part 1)", 21 May 2018, https:// www.aspistrategist.org.au/chinas-strategic-strait-in-the-south-china-sea-part-1/

Dedekoca, Ersin, "ABD - Çin İlişkilerinde Kriz Yönetimi”, ANKASAM Uluslararası Kriz ve Siyaset Araştırmaları Dergisi, Aralık 2017. http://dergipark.gov.tr/download/article-file/391848

Dolven, Ben vd. "Chinese Land Reclamation in the South China Sea: Implications and Policy Options”, Congressional Research Service, 18 June 2015. 
Drifte, Reinhard, "Japan's Policy towards the South China Sea - Applying "Proactive Peace Diplomacy?", Peace Research İnstitute Frankfurt (PRIF) Report,2016. https://www.hsfk.de/fileadmin/HSFK/hsfk_publikationen/prif140.pdf

Dunaway, Wilma A.- Clelland, Donald A. "Moving toward Theory for the 21st Century: The Centrality of Nonwestern Semiperipheries to World Ethnic/Racial Inequality", Journal Of World-Systems Research, C.2, S.2, s.415.

Elleman, Bruce A., "Sovereignty in ASEAN and the problem of maritime cooperation in the South China Sea", (içinde)Bateman-Emmers, a.g.e.

Emeklier, Bilgehan - Ergül, Nihal "Petrolün Uluslararası İlişkilerdeki Yeri: Jeopolitik Teoriler Ve Petropolitik”, Bilge Strateji, C.1, S.3, Güz 2010.

Emmers, Ralf, "The Changing Power Distribution in the South China Sea: Implications for Conflict Management and Avoidance", S. Rajaratnam School of International Studies, September, 2009. https://www.rsis.edu.sg/wp-content/uploads/rsis-pubs/WP183.pdf

Eryiğit, Musab, "Güney Çin Denizinde Sınır Anlaşmazlıkları ve ABD-ÇHC İlişskilerine Etkileri”, DÜBAM Yay. https://www.dunyabulteni.net/file/2012/dubam-guney-cin.pdf

Flecker, Michael, "Early Voyaging In The South China Sea: İmplications On Territorial Claims", The Nalanda-Sriwijaya Centre, NSC Working Paper.

Franke, Maria, "When One Country's Land Gain is Another Country's Land Loss/ The Social, Ecological And Economic Dimensions Of Sand Extraction in The Context Of World-Systems Analysis Exemplified By Singapore's Sand Imports", Institute for International Political Economy Berlin.

Fu, Kuen-chen, "Safeguarding China's National Interests in the South China Sea: Rectification, Services, Leadership, and Maritime Delimitation", China Oceans Law Review, C.13, S.1.

Ganesan, Narayanan- Amer, Ramses, "International Relations in Southeast Asia: Between Bileteralism and Multilateralism", İSEAS, 2010. https://www.hiroshima-cu.ac.jp/peace_e/ category0009/87-international-relations-in-southeast-asia-between-bilateralism-and-multilateralism/

Gao, Zhiguo - Jia, B. Bing, “The Nine-Dash Line İn The South Chına Sea: History, Status, And İmplications", The American Journal of İnternational Law, C.107, S.1, 2013.

Gertz, Bill, "Beijing Adopts New Tactic for S. China Sea Claims", 21 September 2017, https:// freebeacon.com/national-security/beijing-adopts-new-tactic-s-china-sea-claims/

Ghoshal, Baladas, "One Year after the PCA Tribunal Judgment on the South China Sea", 18 July 2017, https://economictimes.indiatimes.com/blogs/et-commentary/one-year-after-thepca-tribunal-judgment-on-the-south-china-sea/

Griffin, Christeon C., "Vietnam's South China Sea Territorial Disputes: A Path to Resolution", Joint Military Operations Department Naval War College", November 2013.

$\mathrm{Gu}$, Junfeng, "Dispute Resolution in the South China Sea: from Joint Development to Joint Protection", Shantou Universty, China. https://warwick.ac.uk/fac/soc/law/research/clusters/ international/devconf/participants/papers/gu_-_dispute_resolution_in_the_south_china_sea.pdf

Gülboy, B. Samih “19. yüzyılda Uzak Doğu Asya’daki Güç Dengesinin Evrimi”, İstanbul Üniversitesi. https://www.academia.edu/10226291/19._Y\%C3\%BCzy\%C4\%B1lda_Uzak_Do\%C4\%9Fu_Asyadaki_G\%C3\%BC\%C3\%A7_Dengesinin_Evrimi

Güneş, Şule A. "Birleşmiş Milletler Deniz Hukuk Sözleşmesi ve Deniz Alanlarının Korunması", AÜHFD, C.56, 2007.

Harada, Yu - Eifuku, Seiya "Chapter 1:The Security of the Sea Significance of the Freedom of Navigation and Related Challenges", East Asian Strategic Review 2018. http://www.nids.mod. go.jp/english/publication/east-asian/pdf/2018/east-asian_e2018_01.pdf

Hart, Michael, "Brunei Abandons South China Sea Claim for Chinese Finance", 4 April 2018, https://www.geopoliticalmonitor.com/brunei-abandons-south-china-sea-claim-for-chinese-finance/ 
Hayton, Bill, “The Modern Origins of China's South China Sea Claims: Maps, Misunderstandings, and the Maritime Geobody", Modern China, May 2018. http://journals.sagepub.com/ doi/abs/10.1177/0097700418771678

Hayton, Bill, "Developments in the South China Sea: Perspectives in the Philippines, Malaysia and Beyond" (içinde) Ed. Murray, Hiebert vd., South China Sea Disputes: Papers From the Fifth Annual CSIS South China Sea Confrence, Rowman\&Littlefield, Semptember 2015.

Hendlin, Yogi, "From Terra Nullius to Terra Communis in advance" https://www.researchgate. net/publication/269792693_From_Terra_Nullius_to_Terra_Communis_in_advance

Heydarian, Richard Cevad, "Malaysia As A New Vortex Of Regional Resistance Against China”, Asia Maritime Transparency İnitiative”, 17 September 2018. https://amti.csis.org/malaysia-new-vortex-regional-resistance-china/

Heydarian, Richard J., "China’s 'New' Map Aims to Extend South China Sea Claims", Asia Times, 29 April 2018. http://www.atimes.com/article/for-weekend-chinas-new-map-aims-to-extend-south-china-sea-claims/

Hong Thao, Nguyen, "Vietnam and the Code of Conduct for the South China Sea", Ocean Development \& International Law, S.32, 2001.

Hong Thao, Nguyen-Ramses, Amer, "Managing Vietnam's Maritime Boundary Disputes”, Ocean Development \& International Law, C.38, 2007.

Hop, Ha Hang “The Oil Rig Incident: A Line Has Been Crossed in Vietnam's Relations with China” http://www.iseas.edu.sg/documents/publication/ISEAS_perspective_2014_61.pdf . 2014:7 (akt.) Khaerani, a.g.e., 2014.

Huei Song, Yann, “The South China Sea Workshop Process and Taiwan's Participation”, Ocean Development \& International Law, S.41, 2010

Hurng-Yu, Chen "The Phantom Of The U-Shaped Line: A Challenge For Southeast Asia's Security", Asia Marıtıme Transparency İnitiative, 9 May 2018, https://amti.csis.org/phantom-u-shaped-line/

Huy, Duong Danh "China’s U-Shaped Line in the South China Sea", https://www.asiasentinel. com/politics/chinas-u-shaped-line-in-the-south-china-sea/

Hyer, Eric, "The South China Sea Disputes: Implications of China's Earlier Territorial Settlements", Pacific Affairs, C. 68, S. 1, Spring, 1995.

Ilgaz, Hatice, "Denizde Bilimsel Araştırmaların Uluslararası Hukukta Düzenlenmesi İhtiyacının Ortaya Çıkışı”, Journal of Naval Science and Engineering, C.5, S.1, 2009.

İkeshima, Taisaku, "China's Dashed Line in the South China Sea: Legal Limits and Future Prospects", Waseda Global Forum No. 10, 2013.

Jawli, Nandini, "South China Sea and India’s Geopolitical Interests", Indian Journal of Asian Affairs, C. 29, S. 1/2 (June-December 2016).

Jaynul, Peter V. Uckung, "Plantıng The Flag In The Islands Of Dispute", Republic of Philippines, National Historical Commission of the Philippines, 2012. http://nhcp.gov.ph/planting-theflag-in-the-islands-of-dispute/

Jorgensen, Malcolm, "China’s Rising Geolegal Sphere", Opinio Juris, 17.10.2017 http://opiniojuris.org/2017/10/17/chinas-rising-geolegal-sphere/

Karabel, Sibel, "Güney Çin Denizỉndeki Çin-Filipinler İhtilafı ve Tahkim Kararının Değerlendirmesi”, Bilgesam Analiz-Doğu Asya ve Pasifik, S.134, Eylül 2016.

Karapınar, Nuray,, "Birleşmiş Milletler Deniz Hukuku Sözleşmesi Ve Deniz Alanlarına İliş̧in Bazı Kavramlar", Doğal Kaynaklar ve Ekoloji Bülteni, S.20, 2015..

Kelly, Todd, "Vietnamese Claims to the Truong Sa Archipelago [Ed. Spratly Islands]", Explorations in Southeast Asian Studies, A Journal of the Southeast Asian Studies Student Association, C.3, 1999.

Kivimäki, Timo War Or Peace In The South China Sea?, Stein, Tonnesson, “Capter 2:The History Of The Dispute ", Nordic Institute of Asian Studies (NIAS), 2002.

Kreuzer, Peter, "Dealing With China in the South China Sea: Duterte Changing Course" PRIF 
Report, S.3, Cover: "Chinese President Xi Jinping welcomes Philippine President Rodrigo Duterte before the Leaders' Roundtable Summit of the Belt and Road Forum (BRF) for International Cooperation at Yanqi Lake", 2018.

Ku, Julian, - Chris, Mirasola, "The South China Sea and China’s "Four Sha" Claim: New Legal Theory, Same Bad Argument", 25 September 2015, https://www.lawfareblog.com/south-china-sea-and-chinas-four-sha-claim-new-legal-theory-same-bad-argument

Kuok, Lynn, Overcoming the Impasse in the South China Sea: Jointly Defining EEZ Claims", East Asia Policy Paper, December 2014, s.5. https://www.brookings.edu/wp-content/uploads/2016/06/overcoming-impasse-south-china-sea-kuok.pdf

Lanteigne, Marc, "Chapter 5: The South China Sea in China's Developing Maritime Strategy", (içinde) Edt.Enrico Fels Truong-Minh Vu "Power Politics in Asia’s Contested Waters Territorial Disputes in the South China Sea", Springer Pub., 2016.

Lelyveld, Michael "Mideast Oil Drives China Disputes", Radio Free Asia, 18 July 2011. https:// www.rfa.org/english/energy_watch/oil-07182011103202.html

Li, Mingjiang, "Reconciling Assertiveness and Cooperation? China's Changing Approach to the South China Sea Dispute", Security Challenges, C.6, S.2, Winter 2010.

Lohschelder, Sarah, "Chinese Domestic Law in the South China Sea", Centre for Strategic \& İnternational Studies. https://www.csis.org/npfp/chinese-domestic-law-south-china-sea

Malik, Mohan, "Historical Fiction: China's South China Sea Claims", World Affairs, May/June 2013.

Marlay, Ross, "China, the Philippines and the Spratly Islands", Asian Affairs: An American Review, C. 23, S. 4 Winter, 1997. https://www.jstor.org/stable/pdf/30172414.pdf?refreqid=excelsior\%3Abad444890e274bfa1c4f7d23edecdf1e

Mattingly, A. David, “The South China Sea Geopolitics: Controversy and Confrontation”, American Military University, 2013.

McManus, John W. “The Spratly Islands: A Marine Park?” Ambio Pub., C.23, S.3, 1994.

Mengtao, Hou - Feilubin, Yuenan, Malaixiya dui Xisha Qundao he Nansha Qundao de Canshi [The Nibblings of the Xisha and Nansha Islands by Vietnam, the Philippines and Malaysia], Selected Papers, supra note 2, at 245 48. (akt.), Shen, a.g.e., 1997.

Mey, Stanley E., "Incident At Mischief Reef: Implications For The Philippines, China, And The United States", Usawc Strategy Research Project, United States War College, 1996.

Mito, Lian A., "The Timor Gap Treaty as a Model for Joint Development in the Spratly Islands", American University International Law Review, C.13, S.3.

Miyake, "Kunihiko, What Are China's Real Core Interests? General Assembly of the World Uyghur Congress Held in Tokyo", Study of "China Inc., S.163, 2012

Mohammad, Dato- Alwi, Ali Bin, “The Conflicting Claims In The South China Sea”, U.S. Army War College, Study Project.

Montemalo, Michael S., "United States Asia Strategy: Policy, Power, Pivot", The Review: A Journal of Undergraduate Student Research, C.17, S. 13. https://fisherpub.sjfc.edu/cgi/viewcontent.cgi?article $=1165 \&$ context $=$ ur

Morton, Katherine, "China's Ambition in the South China Sea: is a legitimate Maritime Order Possible?”, İnternational Affairs, N.92:4.

Nasir, Muhammad, Dahalan Wan SitiAdibah, Wan, "The Islands Claimed By Malaysia In The Spratly Islands: A Review Based On United Nations ConventionOn The Law Of The Sea 1982", IOSR Journal Of Humanities And Social Science (IOSR-JHSS) C.22, September 2017.

Neal, Conan, "Pacific News Minute: China’s Claims to the South China Sea", 5 Jun 2018. http:// www.hawaiipublicradio.org/post/pacific-news-minute-china-s-claims-south-china-sea

Nguyen, Hong, Thao, “ Regional Focus \& Controversies-Vietnam's Position on the Sovereignty over the Paracels \& the Spratlys: Its Maritime Claims", Journal of East Asia International Law, (V JEAIL), S.1, 2012.

Nie, Wenjuan, "Xi Jinping's Foreign Policy Dilemma: One Belt, One Road or the South China 
Sea?", Contemporary Southeast Asia C.38, S.3, 2016.

Noor, Elina - Daniel, Thomas, "Key Issues and Dilemmas for Brunei and Malaysia in the South China Sea Dispute", National Asian Security Studies Program, S.2., December 2016.

Odell, Andrew L.- Castillo, Marlene F., "Vietnam in a Nutshell: An Historical, Political and Commercial Overview", NYSBA International Law Practicum, Autumn 2008 , C. 21, S. 2.

Ohnesorge, Hendrik W. "Chapter 2: A Sea of Troubles: International Law and the Spitsbergen Plus Approach to Conflict Management in the South China Sea", Power Politics in Asia’s Contested Waters. https://www.springerprofessional.de/power-politics-in-asia-s-contested-waters/7492810

O'Rourke, Ronald, "China’s Actions in South and East China Seas: Implications for U.S. Interests-Background and Issues for Congress", Congressional Research Service, 1 August 2018, s.24. https://fas.org/sgp/crs/row/R42784.pdf

O’Rourke, Ronald, "Maritime Territorial and Exclusive Economic Zone (EEZ) Disputes Involving China: Issues for Congress", Congressional Research Service, 2018.

Özkan, Arda, "Kıta Sahanlığının Sınırlandırılmasında Uluslararası Uygulamalar: Sözleşmeler, İçtihat ve Doktrin", International Journal of Social Science, C.31, 2015.

Panda, Ankit, "Why Did China Set Up an Oil Rig Within Vietnamese Waters?: Why now and why Vietnam?", The Diplomat, 13 May 2014, https://thediplomat.com/2014/05/why-did-china-set-up-an-oil-rig-within-vietnamese-waters/

Pao-Min, Chang, "A New Scramble for the South China Sea Islands", Contemporary Southeast Asia, C.12, S.1, June 1990.

Pedrozo, Raul, "China versus Vietnam: An Analysis of the Competing Claims in the South China Sea", A CNA Occasional Paper, August 2014.

Pekcan, Cemre,, "Güney Çin Denizi Sorunu Çerçevesinde Çin-Hindistan İlişkileri”, ÇOMÜ Uluslararası Sosyal Bilimler Dergisi, 2016.

Pinotti, Talita, "China And Vietnam İn The South Chına Sea: Disputes And Strategic Questions", Brazilian Journal of Strategy \& International Relations, C.4, S.8, Jul./Dec. 2015.

Polling, Gregory B., "The South China Sea in Focus: Clarifying Limits the Maritime Dispute", A report of CSİS Sumitro Chair for Southeast Asia Studies, July 2013.

Puri, Raman - Sahgal, Arun, "The South China Sea Dispute: Implications for India”, Indian Foreign Affairs JournaL, C.6, S.4, October-December 2011. http://www.associationdiplomats. org/publications/ifaj/Vol6/6.4/ARTICLE\%203.pdf

Ratner, Ely, "Learning the Lessons of Scarborough Reef”, The National İnterest, 2011. https:// nationalinterest.org/commentary/learning-the-lessons-scarborough-reef-9442

Renato, Cruz de Castro, "The İmpact of Strategic Balance in East Asia on a Small Power's Defence Policy: The Case of Philippines in the Face of the South China Sea Dispute", (içinde) Examining the South China Sea Dispute, CSIS, 2015..

Roach, Ashley J., "Malaysia and Brunei: An Analysis of their Claims in the South China Sea", A CNA Occasional Paper, August 2014, s.I (Foreword Kismı).

Rosen, Mark E., "Philippine Claims in the South China Sea: A Legal Analysis", A CNA Occasional Paper, August 2014.

Rosenberg, David, "Governing the South China Sea: From Freedom Of The Seas to Ocean Enclosure Movements", Middlebury College, Harvard Asia Quarterly-The South China Sea.

Sallah, Asri vd., "Malaysia’s Policy Towards İts 1963 - 2008 Territorial Disputes", Journal of Law and Conflict Resolution, C. 1(5), 2009.

Sands, Gary, Foreing Policy Association, "Brunei, Silent Claimant in the South China Sea", 28 April 2016, https://foreignpolicyblogs.com/2016/04/28/brunei-silent-claimant-south-china-sea/

Schofield, Clive- Storey, Ian, “The South Chına Sea Dispute: Increasing Stakes And Rising Tensions", The Jamestown Foundation, Novermber, 2009.

Sebastian, "Martin A.,Strategic Management for South China Sea: Defence and Security Op- 
tions for Malaysia", Centre for Maritime Security \& Diplomacy Draft Report. http://www. mima.gov.my/images/page/research/Strategic_managment_in_the_South_China_Sea.pdf

Serikkaliyeva, Azhar, "Güney Çin Denizindeki Sınır Anlaşmazlıklarına Çin’in Bakış Açııı”, Eurasian Research Institute, 04-10 Ekim 2016 (Haftalık e-büten), S-84.

Shen, Jianming, "China' s Sovereignty over the South China Sea Islands: A Historical Perspective", Chinese Journal of International Law, C.1, S.1, 2002. https://academic.oup.com/chinesejil/article-abstract/1/1/94/362104

Shen, Jianming, İnternational Law Rules and Historical Evidence Supporting China’s Tide to the South China Sea İslands, University of California, 1997.

Shields, Daniel L., "Working with Brunei to Get the Rebalance Right", United States Ambassador to Brunei Darussalam, https://www.ciaonet.org/attachments/26165/uploads

Siddayao, Corazon M., "Southeast Asia's Offshore Petroleum Resources and the Law of the Sea", Southeast Asian Affairs, ISEAS - Yusof Ishak Institute, 1977, s.84. https://www.jstor.org/ stable/27908307

Storey, Ian "The South China Sea Dispute: How Geopolitics Impedes Dispute Resolution and Conflict Management", Institute of Southeast Asian Studies, Singapore, 2014.

Swaine, Michael.D, "China’s Assertive Behavior Part One: On "Core Interests", China Leadership Monitor, S.34.

Şahin, Diren, "Immanuel Wallersteın'ın Dünya Sistemleri Analizi ve Rusya Federasyonu", KATÜ I. Siyaset Bilimi ve Uluslararası İlişkiler Kongresi Bildiri Özetleri Kitapçığı, 26-27 Ekim 2017.

Şeker, B.Şakir, "Deniz Alanlarının Sınırlandırılması ve Akdeniz Güvenliği”, Uluslararası Ortadoğu Kongresi Bildiriler Kitabı, C.1, Kasım 2011.

Şimşek, Mehtap, “Türk Basınında Vietnam Savaşı: Ulus Gazetesi Örneği”, Ankara Üniversitesi Türk İnkılâp Tarihi Enstitüsü Atatürk Yolu Dergisi, S.42, Kasım 2008.

Tebin, Prokhor, "South China Sea: A New Geopolitical Node", Asia Times, 14 Ekim 2011, http:// www.atimes.com/atimes/Southeast_Asia/MJ14Ae01.html

Thayer, A.Carlyle, "Vietnam's Strategy of 'Cooperating and Struggling' with China over Maritime Disputes in the South China Sea", Journal of Asian Security and International Affairs, Vol 3, Issue 2, 2016. https://journals.sagepub.com/doi/full/10.1177/2347797016645453

Thayer, Carlyle, "Review of the Implementation of the 2002 ASEAN-China DOC and COC and Challenges", Presentation to Seminar-Workshop on the Implementation of the 2002 ASEAN-China Declaration on the Conduct of Parties in the South China Sea (DOC-SCS), May 2015. https://auschamvn.org/wp-content/uploads/2015/05/Review-of-Implementation-of-2002-ASEAN-China-Declaration-on-conduct-of-parties-in-South-China-Sea.pdf

Thayer, Carlyle, "Vietnam's strategies in the South China", http://www.eastasiaforum. org/2017/07/28/vietnams-strategies-in-the-south-china-sea/

Thayer, Caryle, "China’s Oil Rig Gambit: South China Sea Game-Changer?", The Diplomat, 12 May 2014,

Tonnesson, Stein, " The South China Sea in the Age of European Decline", Modern Asian Studies, February 2006, s.2.

Tonnesson, Stein, "Sino-Vietnamese Rapprochement and the South China Sea Irritant", International Peace Research Institute, Security Dialogue, C. 34, S. 1, March 2003, Norway.

Tonnesson, Stein, "Why are the Disputes in the South China Sea So Intractable? A Historical Approach", Asian Journal of Social Science, C.30, S.3, 2002, Norway, s.571. http://www.jstor. org/stable/23654607

Truong Thuy, Tran, "Rebalancing: Vietnam's South China Sea Challenges and Responses", National Asian Security Studies, S.2/3 December 2016.

Turan, İshan, "ABD-Çin İlişkileri Bağlamında Tayvan Sorunu”, Düzce Üniversitesi Sosyal Bilimler Enstitüsü Dergisi, Y1l.6, S.1.

Tüzsüzoğlu, Göktürk, "İkinci Dünya Savaşı Sonrası İngiliz Dış Politikası:İmparatorluk Yaşıyor Mu?", Akademik Bakış Der., S.26, Eylül-Ekim 2011, s.20-21; Denk,a.g.e.,1999. 
Uygur, Erdoğan - Uygur, Fatma, "Fransız Sömürgecilik Tarihi Üzerine Bir Araştırma”, Yıl: 17 S: 3, Aralık 2013.

Velasco, Mark A. M., "Philippines - China Relations: The Case of the South China Sea (Spratly Islands) Claims", Asia Pacific Journal of Multidisciplinary Research, C.2, S.6, December 2014.

Vu, Hai Dang, "A Bilateral Network of Marine Protected Areas Between Vietnam And China: An Alternative To The Chinese Unilateral Fishing Ban İn The South China Sea?", Ocean Development \& International Law, 2013, s.145. https://www.tandfonline.com/doi/abs/10.1 080/00908320.2013.750984

Vuving, Alexander L., "Strategy And Evolution Of Vietnam's China Policy: A Changing Mixture Of Pathways", Asian Survey, C.XLVI, S.6, November/December 2006.

Wang, Kuan-Hsiung, "Bridge Over Troubled Waters: Fisheries Cooperation As A Resolution To The South China Sea Conflicts", The Pacific Review, S.14, C.4.

Welch, David, "Philippines v. China one year later: A surprising compliance from Beijing", Published July 12, 2018, https://www.theglobeandmail.com/opinion/philippines-v-china-one-year-later-a-surprising-compliance-from-beijing/article35660244/

Xu, Beina, "South China Sea Tensions", Counsil of Foreing Relations, https://www.cfr.org/backgrounder/south-china-sea-tensions

Xue, Guifang, "Bilateral Fisheries Agreements for the Cooperative Management of the Shared Resources of the China Seas: A Note", Ocean Development \& International Law, S.36.

Yahuda, Michael, "China’s New Assertiveness in the South China Sea", Journal of Contemporary China, 22:81.

Yllmaz, Sait, "Amerika’nın Filipinlere Askeri Müdahaleleri”, Aydın Adnan Menderes Üniv. https://acikarsiv.aydin.edu.tr/xmlui/bitstream/handle/11547/500/sait24.pdf?sequence=1

Zhang, Feng, "Assessing China's Response To The South China Sea Arbitration Ruling", Australian Journal of International Affairs, C71. S.4.

Zhenhua, Han, "A Compilation of Historical Materials on China's South China Sea Islands" Beijing, Oriental Press, 1988, (in Chinese), 355. (akt.), Keyuan, Zou-Xinchang, Liu, "The Legal Status of the U-shaped Line in the South China Sea and Its Legal Implications for Sovereignty, Sovereign Rights and Maritime Jurisdiction", Chinese Journal of International Law, 2015.

Zhihua, Zheng, "Why Does China’s Maritime Claım Remain Ambiguous?", Asia Maritime Transparency Initiative., June 12, 2015. https://amti.csis.org/why-does-chinas-maritime-claim-remain-ambiguous/

Ziskind, Jonathan, " International Law and Ancient Sources: Grotius and Selden", The Review of Politics, C.35, October 1973.

Zou, Keyuan, "The Chinese Traditional Maritime Boundary Line in the South China Sea and Its Legal Consequences for the Resolution of the Dispute over the Spratly Islands", The International Journal of Marine and Coastal Law, C.14.

\section{4. İnternet Kaynakları}

10 Aralık 1982 tarihli Birleşmiş Milletler Deniz Hukuku Sözleşmesi genel bakış ve tam metin, https://www.un.org/Depts/los/convention_agreements/convention_overview_convention. htm

14 April 2011, New York, http://www.un.org/Depts/los/clcs_new/submissions_files/mysvnm33_09/chn_2011_re_phl_e.pdf

2009 yllında BMKSK'ya sunulan harita http://www.un.org/depts/los/clcs_new/submissions_files/mysvnm33_09/chn_2009re_mys_vnm_e.pdf

2018 Enerji Görünümü: 2040’a Bakış-Asya Pasifik Havzasına Genel Bir Bakış http://www.tuicakademi.org/asya-pasifik-havzasina-genel-bir-bakis/ 
Adjustment Of Fishing Effort In The South China Sea, (presented at the IPFC Committee for the Development and Management of Fisheries in the South China Sea Malaysia), December 1984. http://www.fao.org/3/a-bm759e.pdf

Are Maritime Law Enforcement Forces Destabilizing Asia?, China Power, (İnteractive map) https://chinapower.csis.org/maritime-forces-destabilizing-asia/

ASEAN Foreign Ministers' Statement On The Current Developments In The South China Sea, 10th May 2014, Nay Pyi Taw, https://www.asean.org/storage/images/documents/24thASEANSummit/ASEAN\%20Foreign\%20Ministers\%20Statement\%20on\%20the\%20current\%20developments\%20in\%20the\%20south\%20china\%20sea.pdf

Association of Southeast Asian Nations, "Joint Communique 25th ASEAN Ministerial Meeting Manila, Philippines, 21-22 July 1992", Madde-17. https://asean.org/?static_post=joint-communique-25th-asean-ministerial-meeting-manila-philippines-21-22-july-1992

Birleşmiş Milletler Deniz Hukuku Sözleşmesi, Bölüm VI: Kıta Sahanlığı, Madde-76:Kıta Sahanlığının Tanımı, http://www.un.org/depts/los/convention_agreements/texts/unclos/part6. htm

BM Enformasyon Merkezi Unıc-Ankara, "Birleşmiş Milletler Deniz Hukuku Sözleşmesi”, S.3. http://www.unicankara.org.tr/doc_pdf/denizhukuku.pdf

BM Enformasyon Merkezi Unıc-Ankara, "Birleşmiş Milletler Deniz Hukuku Sözleşmesi”, s.(1415). http://www.unicankara.org.tr/doc_pdf/denizhukuku.pdf

BMye sunulan 6 Mays Tarihli Bildiri http://www.un.org/depts/los/clcs_new/submissions_files/mysvnm33_09/chn_2009re_mys_vnm_e.pdf

BP Statistical Review of World Energy June 2018, http://www.bp.com/statisticalreview

BP Statistical Review of World Energy June 2018, http://www.bp.com/statisticalreview

Brunei Darussalam Büyükelçiliği, http://www.brunei.org.tr/Sayfa.aspx?sayfa_ID=8

Brunei Darussalam Country Report, http://www.eria.org/RPR_FY2015_No.5_Chapter_3.pdf

Carpio, Justice, A.T. “The South China Sea Dispute”, (Power Point) http://philja.judiciary.gov. $\mathrm{ph} /$ assets/files/pdf/learning_materials/lectureseadispute.pdf

Centre For International Law, "2002 Declaration On The Conduct Of Parties In The South Ch1na Sea”, Adopted İn Phnom Penh, Cambodia On 4 November 2002. https://cil.nus.edu.sg/ wp-content/uploads/2017/07/2002-Declaration-on-the-Conduct-of-Parties-in-the-South-China-Sea.pdf

Chairman's Statement Of The 5th East Asıa Summit Foreign Ministers' Meeting Kuala Lumpur “Our People, Our Community, Our Vision”, Final Report, , 6 August 2015, s.5.https://asean. org/wp-content/uploads/images/2015/August/chairman_statement/Chairmans\%20Statement $\% 20$ of $\% 20$ the $\% 205$ th\%20East\%20Asia\%20Summit\%20Foreign\%20Ministers\%20Meeting\%20-\%206\%20August\%202015.pdf

Chapter XXI-Law Of The Sea, https://treaties.un.org/Pages/ViewDetails.aspx?src=IND\&mtdsg_no=XXI-2\&chapter $=21 \&$ clang=_en

China Adheres to the Position of Settling Through Negotiation the Relevant Disputes Between China and the Philippines in the South China Sea. https://www.fmprc.gov.cn/mfa_eng/ zxxx_662805/P020160713368259853890.doc

China calls for 'dual-track approach' on South China Sea, CCTV, https://www.youtube.com/ watch? $=$ LVz3KGFwm_4

China claims its vessels patrolled James Shoal, 31 January 2014, https://www.thestar.com.my/ news/nation/2014/01/31/china-claims-its-vessels-patrolled-james-shoal/

China GovermentChina Adheres to the Position of Settling Through Negotiation the Relevant Disputes Between China and the Philippines in the South China Sea" https://www.fmprc. gov.cn/nanhai/chn/snhwtlcwj/t1380600.htm

China is now the world's largest net importer of petroleum and other liquid fuels, 24 Mart 2014, https://www.eia.gov/todayinenergy/detail.php?id=15531

China İs Now The World's Largest Net İmporter Of Petroleum And Other Liquid Fuels, 24 Mart 
2014, https://www.eia.gov/todayinenergy/detail.php?id=15531

China's Maritime Disputes, https://www.cfr.org/interactives/chinas-maritime-disputes?ci$\mathrm{d}=$ otr-marketing_use-china_sea_InfoGuide\#!/chinas-maritime-disputes?cid=otr-marketing_use-china_sea_InfoGuide

China's envoy to Malaysia makes courtesy call on Defence Minister Hishammuddin, 30 Jan 2014, https://www.thestar.com.my/news/nation/2014/01/30/china-ambassador-courtesy-call-on-malaysia-defence-ministry/

Compare armed forces, https://armedforces.eu/compare/country_China_vs_Malaysia

Continuous boundary line proposed for China's claims in South China Sea, https://www.straitstimes.com/asia/east-asia/continuous-boundary-line-proposed-for-chinas-claims-in-south-china-sea

CRITURK, Analiz Haber: Çin-Brunei Stratejik İşbirliğinin Önemi ve Boyutu. http://www. criturk.com/haber/siyaset/analiz-haber-cin-brunei-stratejik-isbirliginin-onemi-ve-boyutu-68272

Çin Halk Cumhuriyeti’nin Birleşmiş Milletlere sunduğu 7 Mayıs 2009 tarihli metin, http://www. un.org/depts/los/clcs_new/submissions_files/mysvnm33_09/chn_2009re_mys_vnm_e.pdf

Çin'in 14 Nisan 2011 tarihli bildirisi; http://www.un.org/Depts/los/clcs_new/submissions_files/ mysvnm33_09/chn_2011_re_phl_e.pdf

Çin'in 7 Mayıs 2009 tarihli notasl; http://www.un.org/Depts/los/clcs_new/submissions_files/ mysvnm33_09/chn_2009re_mys_vnm_e.pdf

Çin>in Türkiye Büyükelçisi Yu Hongyang: "Güney Çin Denizi anlaşmazlığı müzakere ile çözülür. http://tr.china-embassy.org/tur/xwdt/t1375123.htm

Declaration On The Conduct Of Parties In The South China Sea, http://www.mfa.go.th/asean/ contents/files/other-20130527-163905-069498.pdf

Dış Ekonomik İlişskiler Kurulu, "Vietnam Ülke Bülteni”, Ekim 2009, s.2. https://www.akbank. com/doc/deik/vietnam-2009.pdf

Dış Ekonomik İlişkiler Kurulu, "Vietnam Ülke Bülteni”, Ekim 2009, s.2. https://www.akbank. com/doc/deik/vietnam-2009.pdf

Dış Ekonomik İlişkiler Kurulu, "Vietnam Ülke Bülteni", Ocak 2014, s.2. https://www.deik.org.tr/ uploads/vietnam-ulke-bulteni-2014.pdf

Filipinlerin 5 Nisan 2011 tarihli bildirisi; http://www.un.org/Depts/los/clcs_new/submissions_ files/mysvnm33_09/phl_re_chn_2011.pdf

Fish, Not Oil, At The Heart Of The South China Sea Conflict, Frintj of Nansen Institute, https://www.fni.no/news/fish-not-oil-at-the-heart-of-the-south-china-sea-conflict-article1556-330.html

Food and Agriculture Organization of the United Nations, "The State Of World Fisheries And Aquaculture", 2016, s.44. http://www.fao.org/3/a-i5555e.pdf

Güney Çin Denizi Bölgesel Uyuşmazlıkları, Peace Palace Library, https://www.peacepalacelibrary.nl/library-special/south-china-sea-territorial-disputes/

Güney Çin Denizi Tabloları ve Haritaları - ABD ÇED, Eylül 2003, http://www.southchinasea. org/south-china-sea-tables-and-maps-us-eia/

Güney Çin Denizi Tabloları ve Haritaları - ABD ÇED, http://www.southchinasea.org/south-china-sea-tables-and-maps-us-eia/; Güney Çin Denizinnde ÇHC-ABD Rekabeti, http://www. tasam.org/tr-TR/Icerik/50253/guney_cin_denizinde_chc-abd_rekabeti

Güney Çin Denizi Tahkim Davası (Filipinler Cumhuriyeti/Çin Halk Cumhuriyeti), Çev. Selahattin Doğan, Küresel Bakış, Yll:6, Sayı:21 (Aralık 2016)

Güney Çin Denizi Tahkim Davası (Filipinler Cumhuriyeti/Çin Halk Cumhuriyeti), Çev. Selahattin, Doğan, Küresel Bakış, Yıl:6, Sayı:21, 2016, s.(25-26)

Güneydoğu Asya Ülkeleri Birliği (ASEAN), Uluslararası Örgüt Künyesi, http://www.mfa.gov.tr/ guneydogu-asya-ulkeleri-birligi.tr.mfa

https://acikders.ankara.edu.tr/mod/resource/view.php?id=48534; Hayton, a.g.e., s. 45 . 
https://thediplomat.com/2014/05/chinas-oil-rig-gambit-south-china-sea-game-changer/ https://www.dunyaenerji.org.tr/2018-enerji-gorunumu-2040a-bakis/

IISS Strategic Comments," Vietnam Joined ASEAN", S.5, June, 1995, https://www.tandfonline. com/doi/abs/10.1080/1356788950154?journalCode=tstc20

İnternational Boundary Study Series A: Limits in the Seas, "Territorial Sea Boundary Indonesia-Malaysia", 10 January 1973, s.2. https://www.state.gov/documents/organization/61516.pdf

International Crisis Group, "Stirring up the South China Sea (III): A Fleeting Opportunity for Calm”, Asia Report, May, 2015, s.2. https://www.files.ethz.ch/isn/190793/267-stirring-up-the-south-china-sea-iii-a-fleeting-opportunity-for-calm.pdf

Joint Crisis Committee, "South China Sea: Timeline". https://www.ofs.edu.sg/resources/munofs/wp-content/uploads/sites/18/2015/04/JCC-Research-report.pdf

Keesing's Record of World Events (formerly Keesing's Contemporary Archives), C.10, September, 1956 International. http://web.stanford.edu/group/tomzgroup/pmwiki/uploads/14521956-09-KS-a-EYJ.pdf

Kepulauan Spartly berada berhampiran kawasan EEZ negara Asean, http://www.utusan.com. my/rencana/agama/pertahan-beting-serupai-1.73199

Kıta Sahanlığı (CLCS) Sinırları Komisyonu : baz düzeylerinden 200 deniz mili ötesinde kıta sahanlığı dış sınırları hakkındaki Malezya ve Vietnam’ın Sosyalist Cumhuriyeti tarafından ortak sunumları http://www.un.org/Depts/los/clcs_new/submissions_files/submission_ mysvnm_33_2009.htm

Kuwait News Agency, "China, Malaysia agree joint action plan on strategic cooperation", 04 Jun 2009, https://www.kuna.net.kw/ArticlePrintPage.aspx?id=2004672\&language=en

Limits in the Seas No.117, "Straight Baseline Claim: China", s.(2-3). https://www.state.gov/documents/organization/57692.pdf

Long-term Perspective on Environment and Development in the Asia-Pacific Region https:// www.env.go.jp/en/earth/ecoasia/workshop/bluebook/chapter1-1.html

Malaysia Looks To Chinese Leadership, But Not on South China Sea, 11 October 2018, https:// www.scmp.com/week-asia/geopolitics/article/2168119/malaysia-looks-chinese-leadership-not-south-china-sea

Malaysia Ministry of Foreign Affairs, "Press Release: Statement By Malaysia - Following The Decision of The Arbitral Tribunal On The South China Sea İssue" 12 July 2016. http://www. kln.gov.my/web/ukr_kiev/ps2016/-/asset_publisher/ME2g/blog/statement-by-malaysia-following-the-decision-of-the-arbitral-tribunal-on-the-south-china-sea-issue?redire$\mathrm{ct}=\% 2 \mathrm{Fweb} \% 2 \mathrm{Fukr} \_k i e v \% 2 \mathrm{Fps} 2016$

Malaysian Foreign Policy:Future Direction For 2009-2015, 22 Jun 2009, Putrajaya. http://www. pmo.gov.my/ucapan/?m=p\&p=najib\&id=3925

Malezyảnın 20 Mayıs 2009 tarihli bildirisi; http://www.un.org/Depts/los/clcs_new/submissions_files/mysvnm33_09/mys_re_chn_2009re_mys_vnm_e.pdf

Minister Of Foreign Affairs, "Press Statement: Prime Minister's Working Visit To Brunei Darussalam And The Republic Of Indonesia From 15 To 17 March 2009”. https://www.kln.gov.my/ archive/content.php?t=3\&articleId $=422666$

Minister Of Foreign Affairs, "Press Statement: Prime Minister's Working Visit To Brunei Darussalam And The Republic Of Indonesia From 15 To 17 March 2009”. https://www.kln.gov.my/ archive/content.php?t=3\&articleId=422666

Minister Shahidan Kassim, "Hansard", Parliament of Malaysia (Senate), D.N.14.12.2015. (akt.) Noor-Daniel, a.g.e..,2016, s.9.

Ministry of Foreign Affairs Malaysia, "Press Release: Recent Development in Malaysia's Maritime Areas in the South China Sea", 31 March 2016. http://www.kln.gov.my/ web/kor_seoul/ps2016/-/asset_publisher/ME2g/blog/press-release-:-recent-development-in-malaysia\%E2\%80\%99s-maritime-areas-in-the-south-china-sea?redirect=\%2Fweb\%2Fkor_seoul\%2Fps2016 
Ministry of Foreign Affairs People's Republic of China, "About The Issue of South China Sea", June 2000, http://www.spratlys.org/collection/spratlys_more.htm

Ministry of Foreign Affairs People's Republic of China, "About The Issue of South China Sea", June 2000, http://www.spratlys.org/collection/spratlys_more.htm

Ministry of Foreign Affairs Socialist Republic of Vietnam, "The Hoang Sa And Truong Sa Archipelagoes Vietnamese Territories", 1981, s.8-10. http://nghiencuubiendong.vn/download/ doc_download/157-the-hoang-sa-and-truong-sa-archipelagoes-vietnamese-territories

Ministry of Foreign Affairs Socialist Republic of Vietnam, "The Hoang Sa And Truong Sa Archipelagoes Vietnamese Territories", 1981, s.12. http://nghiencuubiendong.vn/download/ doc_download/157-the-hoang-sa-and-truong-sa-archipelagoes-vietnamese-territories

Ministry of Foreing Affairs of People's Republic of China, "Wang Yi: "Dual-Track Approach" Is the Most Practical and Feasible Way to Resolve the South China Sea Issue", 21 April 2016, https://www.fmprc.gov.cn/mfa_eng/zxxx_662805/t1358167.shtml

Ministry of Foreing Affairs Republic of China (Taiwan), "ROC Government Reiterates İts Position On South China Sea İssues", 31 October 2015. https://www.mofa.gov.tw/en/News_Content.aspx?n=1EADDCFD4C6EC567\&s=F5170FE043DADE98

Ministry Of Foreing Affairs, "Vietnam-China relations push for new height", http://www.mofa. gov.vn/en/nr040807104143/nr040807105001/ns050713135513/view

Ministry of Foreing Japan, "IV. SAN FRANCISCO PEACE TREATY: Joint Compendium of Documents on the History of Territorial Issue between Japan and Russia", 1 March 2001.

Ministry of National Defense The People's Rupublic of China, "China's Military Strategy", http:// eng.mod.gov.cn/publications/2016-07/13/content_4768294.htm

Nanhai Zhudao Are China's Inherent Territory: White Paper, 13 July 2016, https://www.youtube.com/watch? $=$ oN8NTbpETGY

National Archives of Singapore, "Solving Bilateral Dispute Diplomatically-Pedra Blanca/Pulau Batu Puteh", http://www.nas.gov.sg/1stCab/7585/Panels/sec3_2_opt.pdf

Peking Review, C.19, S. 2, June 18, 1976, s.4. http://www.massline.org/PekingReview/PR1976/ PR1976-25.pdf

Permanent Court of Arbitration (PCA), The South China Sea Arbitration (The Republic of Philippines v. The People's Republic of China), The Philippines' Memorial - C.I, s.17.

Permanent Court Of Arbitration, "In the Matter Of The South Chına Sea Arbitratıon- Before -An Arbitral Tribunal Constituted Under Annex VII to the 1982 United Nations Convention On The Law Of The Sea - Between - The Republic Of The Philippines - And -The People's Republıc Of Chına", Pca Case No. 2013-19, 12 July 2016, S.236. https://pca-cpa.org/ wp-content/uploads/sites/175/2016/07/PH-CN-20160712-Award.pdf

Permanent Court of Arbitration, "The South Chına Sea Arbitratıon (The Republic Of The Philippines V. The People's Republic Of China)" Press Release, 12 Jun 2016, s.(1-2).

Permanent Court of Arbitration, "The South China Sea Arbitration (The Republic Of The Ph1lippines V. The People's Republic Of China)" Press Release, 12 Jun 2016, s.(1-2) https:// pca-cpa.org/wp-content/uploads/sites/175/2016/07/PH-CN-20160712-Press-Release-No11-English.pdf

Philippines Hands Protest Note to Malaysia, Associated Press, 20 August 1999. https://academic.oup.com/cjip/article-pdf/9/3/239/6935045/pow008.pdf

Philippines Wins Arbitration Case vs. China, Over South China Sea http://globalnation.inquirer.net/140358/philippines-arbitration-decision-maritime-dispute-south-china-sea-arbitral-tribunal-unclos-itlos

Position Paper of the Government of the People's Republic of China on the Matter of Jurisdiction in the South China Sea Arbitration Initiated by the Republic of the Philippines, 2014/12/07, https://www.fmprc.gov.cn/nanhai/eng/snhwtlcwj_1/t1368895.htm

Position Paper of the Government of the People's Republic of China on the Matter of Jurisdiction in the South China Sea Arbitration Initiated by the Republic of the Philippines, 
2014.12.07, https://www.fmprc.gov.cn/nanhai/eng/snhwtlcwj_1/t1368895.htm

Position Paper of the Government of the People's Republic of China on the Matter of Jurisdiction in the South China Sea Arbitration Initiated by the Republic of the Philippines, 2014/12/07, https://www.fmprc.gov.cn/nanhai/eng/snhwtlcwj_1/t1368895.htm

Proclamation by the Government of the Republic of Vietnam, http://www.nguyenthaihocfoundation.org/lichsuVN/tuyenbo_vnch.htm

Proclamation of independence of Malaya (Kuala Lumpur, 31 August 1957), https://www.cvce. eu/en/obj/proclamation_of_independence_of_malaya_kuala_lumpur_31_august_1957en-51eb6525-30ef-4078-8f83-27deee5e8072.html

Republic of Philippines,Department of Foreing Affairs, Statement of the Department of Foreign Affairs on Developments in the South China Sea, 21 May 2018,. https://www.dfa.gov.ph/ dfa-news/statements-and-advisoriesupdate/16722-statement-of-the-department-of-foreign-affairs-on-developments-in-the-south-china-sea

Republic of Vietnam Ministry of Foreign Affairs, "White Paper on the Hoang Sa (Paracel) and Truong Sa (Spratly) Islands", Saigon, 1975, s.1.

Resmi adı "Filipinler Cumhuriyeti” geçmektedir. Bkz. Türkiye Dışş̧leri Bakanlığı "Filipinler’in Siyasi Görünümü", http://www.mfa.gov.tr/meksika-siyasi-gorunumu_.tr.mfa

RM43bil investment in Malacca Gateway a boost to Malaysia, https://www.thestar.com.my/ news/nation/2015/11/08/china-to-spur-growth-of-ports-rm43bil-investment-in-malaccagateway-a-boost-to-malaysia-says-liow/

San Francisco Treaty, "Japan renounces all right, title and claim to the Spratly Islands and to the Paracel Islands.",https://www.documentcloud.org/documents/1338718-san-francisco-peace-treaty-1951.html

South China Sea: Battleships may lead to war - Malaysia PM, 02 October 2018, https://www. bbc.com/news/av/world-asia-45719090/south-china-sea-battleships-may-lead-to-war-malaysia-pm

Spratlys - Nansha Islands of China, "Vietnam Claims of Spratlys", http://www.spratlys.org/collection/claims/vietnam/vietnam2a.htm

Spratlys - Nansha İslands of China, "Vietnam Claims of Spratlys", http://www.spratlys.org/collection/claims/vietnam/vietnam2a.htm

Stirring Up The South Chına Sea (II): Regional Responses, Asia Report, S.29, 24 July 2012, s.38. https://www.crisisgroup.org/asia/south-east-asia/south-china-sea/stirring-south-china-sea-ii-regional-responses

Territorial Disputes at South China Sea https://www.cfr.org/interactives/global-conflict-tracker?_utm_source=1-2-2\#!/conflict/territorial-disputes-in-the-south-china-sea

Territorial Disputes in the South China Sea (içinde), ed. Enrico Fels-Truong-Minh Vu, Comparative Analysis and Perspectives, Springer, s.31.

Territorial Disputes in the South China Sea, Consil on Foreing Relations, https://www.cfr.org/ interactives/global-conflict-tracker\#!/conflict/territorial-disputes-in-the-south-china-sea

The Age of Imperialism (1870-1914)(online), Part I: Subject Area Reviews with Sample Questions and Answers, s.145. https://s3.amazonaws.com/online.fliphtml5.com/qpfs/sdps/index. html

The İnstitute for Maritime and Ocean Affairs, "China Appreciates Malaysia’s 'Quiet' Diplomacy Approach In Handling South China Sea Issue”. http://www.imoa.ph/china-appreciates-malaysias-quiet-diplomacy-approach-in-handling-south-china-sea-issue/

The Japan İnstitute of İnternational Affairs, "Territorial and Maritime Disputes in the South China Sea and Vietnam's Policy", Indo-Pacific Focus Policy Brief, S.5. http://www2.jiia.or.jp/ RESR/column_page.php?id=314

The National İnterests, "China’s 'New' Map Aims to Extend South China Sea Claims", 30 April 2018, https://nationalinterest.org/blog/the-buzz/chinas-new-map-aims-extend-south-china-sea-claims-25628 
The National İnterests, “China’s 'New' Map Aims to Extend South China Sea Claims”, 30 April 2018, https://nationalinterest.org/blog/the-buzz/chinas-new-map-aims-extend-south-china-sea-claims-25628

The National İnterests, "China's 'New' Map Aims to Extend South China Sea Claims", 30 April 2018, https://nationalinterest.org/blog/the-buzz/chinas-new-map-aims-extend-south-china-sea-claims-25628

The National İnterests, "China's 'New' Map Aims to Extend South China Sea Claims", 30 April 2018, https://nationalinterest.org/blog/the-buzz/chinas-new-map-aims-extend-south-china-sea-claims-25628

The Official Portal Of Malaysia External Trade Development Corporation The National Trade Promotion Agency of Malaysia, "Malaysia's Trade Performance : December 2017 and January - December 2017", http://www.matrade.gov.my/en/malaysia-trade-performance/158-malaysian-exporters/trade-performance-2017

The United Nations Convention on the Law of the Sea (A historical perspective) http://www. un.org/Depts/los/convention_agreements/convention_historical_perspective.htm\#Historical\%20Perspective

The US Department of the Historian, "A Guide to the United States' History of Recognition, Diplomatic, and Consular Relations, by Country, since 1776: Brunei” https://history.state. gov/countries/brunei

The World Bank, "Military expenditure (\% of central government expenditure)", https://data. worldbank.org/indicator/MS.MIL.XPND.ZS?locations=MY\&view=chart.

Malaysia - Military expenditure, https://www.indexmundi.com/facts/malaysia/military-expenditure

Trade Map, https://www.trademap.org/Bilateral_TS.aspx?nvpm=1|458||156||TOTAL ||$|2| 1|1| 1|2| 1|1| 1 \mid 1$

TUİC Akademi, “Bağımlılık Teorisi”, 26 Ocak 2014, http://www.tuicakademi.org/bagimlilik-teorisi/

Türkiye Cumhuriyeti Ticaret Bakanlığı, "Brunei’in Genel Ekonomik Durumu”, https://eb.ticaret.gov.tr/ülkeler/Brunei/genelekonomikdurumdf.ctrl-state\%3Dvcf1x6rv2_276

U.S. Department of State, "United States and China Complete Dialogue on Law of the Sea and Polar Issues”, August 29, 2017. https://www.state.gov/r/pa/prs/ps/2017/08/273701.htm

U.S. Department of State, "United States and China Complete Dialogue on Law of the Sea and Polar Issues", August 29, 2017. https://www.state.gov/r/pa/prs/ps/2017/08/273701.htm

U.S. Energy İnformation Adminsration, "Analysis- Energy Sector Highlights" https://www.eia. gov/beta/international/country.php?iso $=\mathrm{BRN}$

U.S.-Malaysia Partnership, 15 February 2012, https://2009-2017.state.gov/t/pm/rls/rm/184846. htm

UN Law of the Sea, "Law on the Territorial Sea and the Contiguous Zone of 25 February 1992". http://www.un.org/depts/los/LEGISLATIONANDTREATIES/PDFFILES/CHN_1992_ Law.pdf

United Nation Oceans\&Law of the Sea, "Commission on the Limits of the Continental Shelf (CLCS) Outer limits of the continental shelf beyond 200 nautical miles from the baselines: Submissions to the Commission: Joint submission by Malaysia and the Socialist Republic of Vietnam".

United Nation, "Brunei Darussalam's Preliminary Submission Concerning The Outer Limits Of İts Continental Shelf”, http://www.un.org/Depts/los/clcs_new/submissions_files/preliminary/brn2009preliminaryinformation.pdf

United Nations Convention on the Law of the Sea, Article 47: Archipelagic baselines, s.40. http://www.un.org/depts/los/convention_agreements/texts/unclos/unclos_e.pdf

United Nations Treaty Collection, Chapter XXI. Law of The Sea. https://treaties.un.org/pages/ ViewDetailsIII.aspx?src=TREATY\&mtdsg_no $=$ XXI-6\&chapter $=21 \&$ Temp $=$ mtdsg $3 \& c-$ 
lang=_en

United States Central İntelligence Agency, "Central Intelligence Agency map series: Brunei Maps 1984", https://www.loc.gov/resource/g81985.ct001596/?r=-1.18,0.065,3.36,1.272,0

United States Department of State: Bureau of Intelligence and Research, "Limits in the Seas, Straight Baselines: Vietnam", S.99, 12 December 1983, s.(3-4) https://www.state.gov/documents/organization/58573.pdf

United States Energy İnformation Adminsration, "Contested areas of South China Sea likely have few conventional oil and gas resources", https://www.eia.gov/todayinenergy/detail. php?id=10651

United States Holocaust Memorial Museum, https://www.ushmm.org/wlc/tr/article.php?ModuleId $=10007306$

United States Institute Of Peace (Special Report), “The South China Sea Dispute: Prospects Of Preventive Diplomacy", August 1996. https://www.usip.org/publications/1996/08/south-china-sea-dispute-prospects-preventive-diplomacy

US accuses China of 'destabilising' acts in South China Sea, Saturday 31 May 2014, http:// english.ahram.org.eg/NewsContent/2/9/102578/World/International/US-accuses-China-of-destabilising-acts-in-South-Ch.aspx

USGS, "World Petroleum Project, An Estimate of Undiscovered Conventional Oil and Gas Resources of the World-2012", https://pubs.usgs.gov/fs/2012/3042/fs2012-3042.pdf

VGP News, "Vietnam Deniz Polisini Yapilandırdı", 15 Nisan 2014, http://baodientu.chinhphu.vn/Hoat-dong-cua-lanh-dao-Dang-Nha-nuoc/Ra-mat-luc-luong-Kiem-ngu-VietNam/197269.vgp

Vietnam, China secure 19 cooperation deals, 13 November 2017, Nhan Dan Online, http://en.nhandan.com.vn/politics/external-relations/item/5639602-vietnam-china-secure-19-cooperation-deals.html

Wawasan Brunei 2035, https://www.gov.bn/SitePages/Wawasan\%20Brunei\%202035.aspx

Xi Urges Peace, Asserts Sovereignty, During ASEAN Trade Fair, https://www.youtube.com/watch?v=1bRFSuWNZcQ 